\title{
Re-Constructing Aspects of History through Pottery Productions up to 2000 AD of the Bisu People of Obanliku Local Government Area of Cross River State, Nigeria
}

\author{
Kyegh, Aov Thaddeus ${ }^{\mathrm{a} *}$, Peters Beatrice Ugieye ${ }^{\mathrm{b}}$ \\ kyeghfateraov@yahoo.com* \\ ${ }^{a}$ Department of History and International Studies, Federal University Lafia, Nasarawa State, Nigeria \\ ${ }^{b}$ Department of Visual and Creative Arts, Federal University Lafia, Nasarawa State, Nigeria
}

\begin{abstract}
Studies have shown that man existed for about two million years, while documentation via writing began about 5,000 years ago, that is about $3000 \mathrm{BC}$, yet it did not commence simultaneously in all parts of the world. The invention of writing made some Western scholars to assert that history began with writing. Such perception made some scholars to classify the activities of unlettered societies as pre-history. The classification notwithstanding, historians and archaeologists have employed professional methods to reconstruct activities of the human past before the proto-history. It is in this connection that the research has undertaken to study a pre-history of the Bisu people in Obanliku Local Government Area of Cross River State, Nigeria, through their Pottery Production. The study reveals that pottery production was one of the vehicles for the socio-economic and political activities of the Bisu. That through pottery, some socio-economic and political aspects of a history of the people can be identified and reconstructed. The research used oral interview, written records and archaeological interpretations to arrive at the result. The research maintained that apart from the Bisu pottery, other cultural materials of the past could also be used to reconstruct other aspects of global prehistory. The study concluded that history began concurrently with the origin of man long before modern writing, therefore, studies in early histories of late writers like the Bisu should be encouraged.
\end{abstract}

Key words: Bisu, pottery, reconstruction, writing, archaeology

\section{Introduction}

Pottery production is a worldwide craft that has been in practice from the Upper Paleolithic Age or the end of the Old Stone Age. As man advanced in pottery technology, he designed pots in various sizes and shapes which define their functions or utility which unconsciously recorded a history of the producers (Anders and Innocent, 2010). For instance, the Kapwirimbwe of the Lusaka Plateau in Zambia in the $5^{\text {th }}$ Century AD had a unique pottery type characterized by high frequency of thick rims, few comb stamped technique and variety of incised decorative motifs each depicting or representing an activity of the people. Through pottery, other cultural features were identified such as domestication of goats, hunting wild animals, extensive iron working and few copper metallurgy (Okpoko and Derefake, 2012). The study further stated that there were evidences of similar pottery technology across Africa, especially in farming communities which the Bisu is not an exception. To ensure continuity, pottery art metamorphosed into modern ceramics with pictures of events such as farming and sports in some civilizations (Moloney, 1995). Similarly, the sizes of the pottery products define the historical antecedent of the Bisu Ethnic group. The Bisu people comprises of five villages namely; Bukemanya, Bayayam, Busanfon, Ighare, and Bayaga, all in Obanliku Local Government Area. They were formally in Obudu Local Government of Cross River State until August 27, 1991, when Obanliku Local Government was carved out of Obudu LGA. It shares boundaries with the neighbouring State of Benue in the west, Obudu LGA in the north, Boki LGA and the Republic of Cameroon in the east (Udey, 2007). The Bisu ethnic group still insists that pottery production in their Community is an indigenous practice, which means it has a lot of history in stock for generations unborn to benefit from. It was based on the forgoing that the research has undertaken to reconstruct a history of the Bisu using their pottery products as a focal point. 


\section{Historical Background of Pottery Production}

Because of its durability in whole or fragments ceramics survive from millennia at archaeological sites. Consequent upon its ability to withstand weather conditions, many prehistoric cultures are named after the pottery materials within their culture and same could be used to study histories of the creators of such cultures. In the light of this, the study will proceed to discuss the origins of pottery production in some parts of the world.

New archaeological finds are emerging regularly as soon as investigations or researches are completed in a chosen area. For instance, in 2007, studies asserted that the earliest pottery in the world was in southern Japan among the Jomon hunter-gatherers dated 10,500 BC (Fagan, 1980). However, another study stated that by 2012, the earliest pottery found anywhere in the world, dating to 20,000 to 19,000 years before the present, was found at Xianrendong Cave in the Jiangxi province of China at the height of the ice age, long before the beginnings of agriculture and permanent settlements (Krause, 2006). The dates show that after 2012, it was likely that new findings might be older than that of China.

The quest for new finds led to the study of a Sub-Saharan Africa ethnic group, the Bisu potters who claim that pottery was independently developed in their community. In support of the independent initiative, Krause (2006) periodized pottery production in sub-Saharan Africa to be during the 10th millennium BC, with findings dating to at least 9,400 BC in the case of Mali. Again in 2007, Swiss archaeologists discovered pieces of what may be considered as the oldest pottery in Africa at Ounjougou in Central Mali, dating back to at least 9,500 BC (Krause, 2006). The Malian finds date to the same period as similar finds from East Asia-the triangle between Siberia, China and Japan-East Asia. The same study further states that in the Near East the earliest history of pottery production can be divided into four periods, namely: the Hassuna period (7000-6500 BC), the Halaf period (6500-5500 BC), the Ubaid period (5500-4000 BC), and the Uruk period (4000-3100 BC).

By 3,000 BC pottery extended to Europe with ranges of indigenously developed styles largely assembled by European prehistoric nomadic hunter-gatherers which marked the first use of clay vessels by Western peoples (Rebecca and Williams, 2017). Pottery production advanced to such a level that it could write history through pictorial designs. For instance, the Yangshao pottery from Bampo-China show fish motifs as back designs, indicating that the bearers of the culture were fishermen as well. These findings can be used to authenticate the autochthony claims of the Bisu potters in pottery production.

The historical background shows that pottery works started independently among the early people of the earth. Incidentally their functions were almost similar to each other. Sutton and Yohell, (2008) affirms that most of subsistence activities revolve around food; getting, processing, storing, distributing, cooking, and eating food. As pottery technology advanced its utilization went beyond food to include aesthetics, decoration or beautification and symbols. By and large, Iron Age archaeologists have observed a change in pottery, from a predominantly thick-bodied ware, largely decorated with comb stamps towards thinner wares, carrying painted or textured designs. Such pottery became indispensable in this period of human life as it was in some societies within the period of study in the A.D (Phillipson, 1993).

\section{Conceptual and theoretical issues}

Great part of the history of pottery is grouped under pre-history by archaeologists; which means they are cultures of the pre-literate societies. In this research it is possible to argue that the word pre-literate societies can only be used in the Western sense of modern writing. Otherwise, pottery production itself was a form of writing represented in symbols or marks that can be used to recover a history of a people. For instance, the 'Moche' had no written language but vividly portrayed their life in pottery, metalwork and textiles (Moloney, 1995). They show rulers, priests (medicine men), warriors, goods, and ordinary people. They depict plants, animals, hunting, fishing etc. That is why the research is on a history of the Bisu assessable through pottery production. Potteries are manmade objects of baked clay produced by molding or shaping moist clay and hardening it by heating in a kiln (Udey, 2007). For instance, the production of pots, vessels, vases, plates, or sculptured articles is done by the baked clay method. The essence of heating the clay objects is to ensure its durability. In this connection, all the decorative attachments that define the 
socio-economic and political life of the people are preserved on the ceramics. What this practice reveals are that, for a researcher to study a pre-history of an ethnic group, the use of pottery products is obligatory. It is in the light of the foregoing that the investigation of the Bisu pottery production practice to study their history cannot be overemphasized.

Furthermore, to understand the concepts of pottery production, theoretical explanations are very vital. In this research, the Universal Theory of Pottery Production has been solely selected. In the Universal Theory of Pottery Production, an archaeologist, Richard A. Krause (2006) posits that the careful study of an archaeological site's ceramics can be used to formulate a step and stage theory of pottery production in an area. This could be achieved by comparing the results of enquiries conducted at different sites over times, which may enable archaeologists to create a general ethnographic theory of pottery production. The analysis further revealed potsherds from the highly stratified Puerto Rican Site of Paso del Indio using the concepts of attribute, mode, feature, association, site, analysis, and classification to categorise their production and decorative techniques and assigns the ceramics to previously discussed potting tradition in the area of study. The theory concentrated on the manufacturing process which includes decoration for the classification of the North American, Carribean, and South American prehistoric pottery. This study exposed the socio-economic, scientific and cultural life of the region and their relations to others. The review of the compositional investigations and studies of pottery production before pottery became part of a culture, shows that there were four conditions that must be generally considered for the production of pottery (Prudence, 1996).

Firstly, a surveyed functional and stylistic analyses and pottery origins indicates that, there must be usable clay available. Archaeological sites where the earliest pottery was found were near deposits of readily available clay that could be properly molded and fired. China for example has large deposits of a variety of clays, which gave them an advantage in early development of fine pottery. Many countries have large deposits of a variety of clays. Similarly, clay is available within the Bisu community.

Secondly, it must be possible to heat the pottery to temperatures that will achieve the transformation from raw clay to ceramic, which is also a common practice in the study area.

Thirdly, the potter must have time available to prepare, shape and fire the clay into pottery which became possible when man started living a sedentary life. And it also accounts for why most potters in Africa particularly the Bisu potters' work on their industry during leisure time.

Finally, there must be a sufficient need for pottery in order to justify the resources required for its production. In Bisu society, pots served four principal functions; domestic, ceremonial, commercial and aesthetic. As such there was growing demands for pottery wares all year round and potters had insatiable desire to produce more. In sum, the four conditions that must be present before successful pottery production can become a culture as suggested by Krause (2006) were also available in the study area.

The Theory further maintains that, baked clay containers of all shapes and sizes require a multi-stage, multistep construction effort (Hugh, 2017). Outside this, there is a general production sequence in pottery which is also prevalent among the Bisu; which shows that the universal idea of pottery production was coeval with the ethnic group. In the sequence, the potter source the clay, prepares the clay, build the vessel into the desired form, decorate the vessel, dry the vessel, and fire the vessel (Krause, 2006, Hugh, 2017 and Jeff G. and Debby S. 2018). This section therefore provides the theoretical framework for the study of the Bisu prehistory pottery products.

\section{How pottery production can be used to reconstruct a history of the Bisu}

Understanding a history of pottery production can be assessed through careful observation and interpretations of the methodologies used by the potters. For instance, studies have shown that the methodologies used to produce pottery in early Sub-Saharan Africa were divided into three categories: techniques visible to the eye (decoration, firing and post-firing techniques), techniques related to the 
materials (selection or processing of clay, etc.), and techniques of molding or fashioning the clay (Vasant and Prabodh, 2009). These three categories can be used to consider the implications of the reoccurrence of a particular sort of pottery in different areas. Generally, the techniques that are easily visible (the first category of those mentioned above) are thus readily imitated, and may indicate a more distant connection between groups, such as trade in the same market or even relatively close proximity in settlements. However, other techniques require more efforts to replicate such as the selection of clay and the fashioning of clay through craft specialization (Vanessa, 2019) may indicate a closer connection between peoples, as these methods are usually only transmissible between potters and those otherwise directly involved in production. Such a relationship requires the ability of the involved parties to communicate effectively, implying pre-existing norms of contact or a shared language between the two. Thus, the patterns of technical diffusion in pot-making that are visible via archaeological findings also reveal patterns in societal interaction. Being members of the Sub-Saharan Africa, these categorizations applied to the intergroup relations between the Bisu and their neighbours; especially the Tiv.

Material acquisition for and types of pots produced also recorded a history of the Bisu. For instance, the process of obtaining clay moist or dry, pebbles or stones, designed sticks, tree paint, nails, local net or jute bag, bamboo stick or leaves, fire wood and firing methods were the same across the areas that bordered the Bisu community (Uchua, 2019). These were evidence of close associations and neighborliness. In addition, they used same hand method and tools for molding such as 'ushan' leaves of a tree called 'akinde' in Tiv. It is used to smoothen the brim of pots to perfect its roundness. The use of 'ugam' 'kper in Tiv' a net-like jute bag to provide a rough bottom in which helps the pots to have a firm grip on the ground or on fire stand. The 'ukpunne' 'ikpine' in Tiv used for painting of the ceramics and the likes, were evidence of co-existence, nearby settlements or understanding of each other's' language (Uchua, 2019). The tools were used to produce early traditional pots such as; 'shichu chan': drinking pot, 'shichu ligee le umu' cooking pot and fetching water, and 'adiakum' spiritual or medicine pot etc. The designs of pots began tilting towards the manufactured types which was evidence of contact of the people with the outside world. It will be recalled that Calabar Zone was one of the earliest places visited by non-Africans in the $15^{\text {th }}$ Century (Dani, 2011). By the first half of the 1900s, potters began to mold pots with stools, some open like basins, there were kettle pots 'shichu umu le uto,' palm wine and entertainment water pot, two in one 'ula ifuwa', perforated pots 'ulum', 'baaf' in Tiv, 'shichu' flower, flower pot, 'udum', musical pots, in addition to the use of European dresses, furniture and architecture (Unung, 2019).

Another area of the Bisu history was also evident in the functions of pottery wares. Udey (2007) identifies three principal functions of pottery products, namely; domestic, communal and aesthetic functions. For domestic purposes, pots were used for storage, fetching water, cooking food and medicine, boiling water for other uses and the conveying of food stuff. These functions show that as early as pottery production began in Bisu the people had knowledge of agriculture. They produce and conveyed their products to their houses. They took some to the markets or relatives and store some using different types of pots. With food to feed the population, the people moved into communal functions to mark their leisure times. More over pottery production itself was a leisure time occupation for those who were experts in the art especially women in the Bisu society. In that light, communal activities such as musical performances, festivals and other celebrations such as intermarriages, spiritual or religious functions took central stage in which pots were used to cook and serve guests as well as for incantations. For beauty or aesthetic purposes, product painting or staining, impressions, perforations, discoloration and relief designs were introduced by the potters in Bisu (Uchua, 2019). All the aesthetic ceramics had some specific functions but above that they attracted customers and expressed the creativity of the producer. In discussing the functions, Eddy maintains that in archaeological records one of the criteria of chiefdom organized societies was the presence of ceremonial as well as utilitarian pottery (Eddy, 1991). Similarly, among the Bisu, domestic, 
communal, commercial and aesthetic functions would not have been possible without an organized chiefdom (Unung, 2019).

Economically, pottery wares have always been part of the market commodity. The legal tender was the exchange of goods; trade by barter, before the introduction of local currencies and modern coins and notes (money) (John, 2019). For instance, in the Tiv markets, pots were exchanged for Tiv fowls, beniseed, gari etc. The quantity to be carried to the market per head depended on the sizes of the pot (s) and the strength of the carrier. This trade spanned from precolonial, colonial and postcolonial periods up to 2000AD. The pottery wares were sold at the village markets, the next-door local Government markets of Obudu and Gakem in Cross River State, and Agbo (Vandeikya) and Adikpo in neighboring Benue state (Anwafoabe, 2019). The trade was very much self-sustaining; hence it helped satisfy some of the basic needs of the people such as the training of children in schools at all levels.

There was the division of labour; women molded pots at home and took care of children and other family chores. Men believed that making of pot was simpler than farming; therefore, the men cultivated farms, keep and harvest or extract honey kept in pots (hives), and hunted animals which required energy, perseverance, endurance and for defense (Uchua, 2019). The gender discrimination among the Bisu demonstrated the claim of male superiority over women since creation by all races of the world.

By 1960s, modern non indigenous tools were used in obtaining clay in Bisu such as cutlasses, knives, diggers, and small hoes, while iron nails, waterproof and nylon were added to the materials used in preparation of the pots before firing (Afachung, 2019). The inclusion of manufactured items such as sweet, biscuits and chewing gum as sacrificial materials to be kept in Adiakum was also part of intergroup relations in the 1960s especially trading. As earlier discussed above, because of the European early contact with the Cross River ethnic groups which the Bisu was part of, the use of Western dresses, the bench or stool for sitting to mold pots was another historical antecedence connected with the life of people outside their environment.

\subsection{The challenges of pottery making in Bisu}

The impact of the Western Civilization on the Bisu Pottery production was enormous. It brought a reduction in apprenticeship and pottery production activities. The demand for the local products was limited to the locals, the poor in towns, those who needed it to boil herbal medicines and decorated pots to beautify their scenery. The decline in pottery production was not only among the Bisu, in $1980^{\mathrm{s}}$ Ghana, the Krobo Village an outshoot of the ancient Bono Manso State, archaeologists could identify only five women ages fifties to seventies who ceased potting not less than ten years ago who could demonstrate in the most traditional way they remember typical ancient Bono pots (Gyamfi, 1980). The dying craft has made indigenous people to concentrate on foreign synthetic wares (enamels and plastics) which most people have substituted for the ceramic vessels that can easily get broken. In addition, the plastics, stainless steel, iron and aluminum products were easily manufactured in large quantities and were lighter to convey from one destination to the other without incurring much time, cost, weight and losses. This has greatly affected the economic fortunes of few potters left in the business especially the aged women who are not into any other entrepreneurial scheme or have no other serious economic means of survival.

The introduction of metal pots and the use of kerosene stoves, electric stoves, flask water heaters and gas cookers which replaced fire wood were another heavy blow on indigenous pottery. They use cleaner fuels in cooking, while smoke generated by firewood expose women to diseases such as tuberculosis, asthma, high blood pressure and lung cancer (Tope, 2017). Ani and McKay (2015) maintains that individuals that live in households that cook with firewood have 11.2 per cent lower lung capacity 
measurement compared to those cooking with cleaner fuels. These campaigns rightly or wrongly have negatively affected pottery production; hence clay pots are bed fellows of firewood especially during production and later cooking. In addition, the $19^{\text {th }}$ Century, saw the invention of many brands of 100 to 5,000 litres or more containers for the storage of agricultural products, water, and oils very common in the open market across Nigeria which have replaced the hitherto clay vessels.

The inability of traditional African potters to be dynamic in their practice is another challenge facing the occupation. The new generation is not adopting the Neolithic 'New Stone Age' village craft and the old generation is fast dying out. More so, the old generation has no formal education which is a yard stick to enable them to improve on their job (Barrie, 2005). If the aged illiterate women are well trained to be able to transmit the same knowledge to their offspring there will be continuity. Similarly, if the men take as a unisex occupation that is viable, the challenges will be reduced.

There is also the twin challenge of finance and labour. The job is labor intensive ranging from acquisition of clay to its additive nature of production and the repetitive activity of destroying what was already molded to re-pound and produce same or another type of ceramics. This is because any inefficiency in the production process has multiplying effects on costs; time and labour (Ani and McKay, 2015). In an era where the older generation is becoming weaker every day, they have to buy clay, supplies and equipment. They lack fundamental business principals in producing pottery. Our system of formal education also does not help matters. They do not receive training to survive in a business environment. They do not receive financial education required for success, rather they acquired academic education meant to read, write and do mathematics or professional education which is learning to work for money (Kiyosaki, 2009). That is why many of our graduates in Visual and Creative Arts fail to earn a living from their craft.

Both the government and the locals are not aware of economic potentials in pottery business. The cost of modern ceramics is very high, but the people have remained with their remote indigenous knowledge, thereby robbing them of the opportunity to make real money from ceramics. This challenge made pottery production among the Bisu very difficult. Therefore, their economic history in relation to pottery production suffered a setback. Off course, both the old potters and the new generation are not aware that allowing indigenous pottery production to get extinct is denying the people, well-wishers and researchers the knowledge of their rich history.

\subsection{The way forward}

For the pre-history of the Bisu to survive, the youths have to be engaged in the production of pottery materials both males and females. It should be a unisex profession. Researchers have suggested that pots producers should learn to appreciate their creativity, because it is a way of expressing their talents (Ani and Mckay, 2015). By their creativity, artists always show their culture and the environment they live in. It is an opportunity to show-case one's self-identification, self-expression, self-esteem, bolster confidence and ensure full concentration without been pushed away by side attractions and other worries (Tope, 2017). In addition, physically pottery production exercises the whole body especially the hands, wrists, brain and arms. It is a group activity usually observed and discovered through archaeological research and preserved in museums. Pottery production can improve quality of life of the potters by embarking on new creations, learning new techniques and by finishing their creations which can contribute to a lifetime commitment of learning and maintaining a productive hobby (Katelyn, 2019). A Bisu potter who focuses on these approaches will make a great revolution in indigenous pottery. 
In addition to the above, enlightenment campaigns and workshops should be held in Bisu to educate potters on the benefits of the trade. Government, civil society organisations and private sectors-proprietors should also assist in opening trade fares, workshops to expose economic potentials of pottery business. These measures will help the potters to upgrade their production to modern ceramics to accrue more money. The enthusiasm will lead to the maintenance of their history courtesy of their ceramics. They should capitalize on the availability of small-scale business loans offered by the Nigeria government to expand their pottery production, improve standard and enhance mass production.

The knowledge of the benefits of making pottery is so much rewarding. For instance, with availability of clay, the potter can within limits, control the size and shape of the finished piece much more than with other materials. Similarly, sedentary life can help women to make large, heavy, thick-walled vessels. In southwestern United States, the invention of pottery allowed Pueblo Indians to boil their food, which make it more digestible and nutritious, and a broken pot could easily be replaced since clay was close by (Fagan, 1980). Potters in Bisu should improve on the method of production so that pots could be used on stove and gas cookers that use clean fuels such as kerosene and gas during cooking. The improved production will ensure lighter but strong vessels that could be used for storage of liquids and other solid products or materials.

\section{Conclusion}

The research has shown that the Bisu were part of the $15^{\text {th }}$ Century mass movements of ethnic groups in Africa. They probably migrated and settled in the present location during the Century and established cordial relationship with their neighbours. They were probably part of the formative stage of the New World Civilisation marked by the production of true fired ceramics for cooking, storing, and preserving food and liquids (Eddy, 1991). Their civilization was demonstrated by their pottery production which was a universal technology adopted by creative ethnic groups that had scientific knowledge to identify clay sites suitable for ceramics. Ceramics types unveiled the different historical development in the culture of the people exemplified by the pots size, shape, design, decoration, domestic use, short and long distant trade; from trade by barter to the use of modern currency. More importantly, ceramics gave them a strong economic base. All these were made possible because of effective traditional leadership; which ensured good governance resulting to peaceful co-existence of the Bisu community itself and with their neighbours. Consequently, it led to the creation of an enabling environment for creative minds to produce varieties of ceramics and other associated socio-economic and political activities. Finally, the development of a business plan and an organized, efficient approach to pottery production and marketing is the answer to all foreseen challenges identified above.

\section{Acknowledgement}

The completion of this research could not have been possible without the participation and assistance of so many people whose actions led to the success of this work. Their contributions are sincerely appreciated and specially recognized. However, the authors hereby express deep gratitude to scholars whose works provided the foundation for the study. And to those who granted oral interview to help gather the required data for the study. 


\section{References}

Afachung P. (2019). Interview by the authors. Obanliku.

Anders L. \& Innocent P. (2010). Ceramics and change: An overview of pottery production techniques in northern South Africa and eastern Zimbabwe during the first and second millennium AD. Journal of Archaeological and Anthropological Sciences, Volume 2, Number 3. Retrieved February, 2021 at https://www.researchgate.net/publication/226896565

Ani R. S. and Mckay A. (2015). The Impact of Cooking with Firewood on Respiratory Health: Evidence from Indonesia Journal of Development Studies 51(12):1-15. Retrieved February, 2021.

https://www.researchgate.net/publication/282532206_The_Impact_of_Cooking_with_Firewood_on_Respir atory_Health_Evidence from_Indonesia

Anwafoabe T. (2019). Interview by the authors. Obanliku.

Barrie, P. (2005). Serious Money; how to make and enjoy it, (Edo State, Nigeria, Marvellous Christian Publications p. 203

Dani, L. (2011). Nigerian Dress the Body Honoured, the Costume Arts of traditional Nigerian Dress from Early History to Independence, (Lagos, Centre for Black and African Arts and Civilisation,147

Fagan, B.M. (1980). People of the earth, An Introduction to World prehistory, (New Jersey, Pearson Education INC, p. 230

Eddy, F.W. (1991). Archaeology, A cultural Evolutionary Approach, (New Jersey, Prentice Hall, Inc. 1991),292

Gyamfi, K. (1980). 'Traditional Pottery Technology at Krobo Takyiman (Techiman, Ghana: An EthnoArchaeological Study' in West African Journal of Archaeology vol. 10, (Ibadan, Claverianum Press, 1980), 104

Hugh Prysten (2017). My step by step process for making handmade pottery. Retrieved January 17, 2021 at https://www.hughprysten.com/blogs/news/my-step-by-step-process-for-making-handmade-pottery

Jeff G. and Debby S. (2018). The Production of Pottery. College of Arts and Sciences, University of Colorado. https://www.colorado.edu/classics/2018/06/15/production-pottery Retrieved 25 February, 2021.

John T. (2019). The Transition from Barter Trade to Impediments of the Dollar System: One Nation, One Currency, One Monopoly. Retrieved 21 January 2020 at

https://www.researchgate.net/publication/331559802_The_Transition_from_Barter_Trade_to_Impediments _of_the_Dollar_System_One_Nation_One_Currency_One_Monopoly

Phillipson D. W. (1993). African archaeology. Cambridge University Press, Cambridge

Katelyn B. (2019). Top 10 Health Benefits of Pottery. Retrieved February,2021 at https://weheartit.com/articles/327729158-top-10-health-benefits-of-pottery

Krause, R.A. (2006). A Universal Theory of Pottery Production, Carribean Archaeology and Ethnohistory Series, the Alabama University Press, 224

Kiyosaki, R. T. (2009). ICH Dad's Conspiracy of the Rich. The 8 new rules of money, New York, Hachette Book Group, 169, 217. 
Moloney N. (1995). The Young Oxford Book of Archaeology, (New York, Oxford University Press, 83

Okpoko, A.I. \& Derefaka, A.A. (2012), Archaeology and Early History of Africa, (Nsukka, University of Nigeria Press, 190

Prudence M. R. (1996). Recent ceramic analysis: 2. Composition, production, and theory. Journal of Archaeological Research, Vol. 4, No. 2, 1996) (pp. 133-163). Retrieved 27 February 2021 at https://link.springer.com/journal/10814

Rebecca F., William D. (2017). Palaeolithic ceramic technology: The artistic origins and impacts of a technological innovation. Journal of Quaternary International 441(2017)3-11. Retrieved February, 2021 at https://www.researchgate.net/publication/314169419

Sutton, M.Q. \& YoheII, R.M. (2008). Archaeology the Science of Human Past, Boston, Pearson Education Inc, 250

Tope A. (2017). Side effects of cooking with fire wood. Retrieved April, 2018 at https://www.informationng.com/2017/09/512769.html

Uchua Cyprian S. U. A. (2019). Interview by the authors. Obanliku.

Udey, B.U. (2007). The Production of Ceramics in Bisu, a Study of Forms, Functions and Aesthetics, unpublished BA Project, Cross River University of Technology, Calabar, Cross River State, Nigeria. 7

Unung A. (2019). Interview by the authors. Obanliku.

Vasant S. and Prabodh S. (2009). Ceramic Production Techniques. Bulletin of the Deccan College Post-

Graduate and Research Institute. Vol. 68/69 (2008-2009), pp. 1-21 (21 pages). Deemed University Retrieved 28

February, 2021 at https://www.jstor.org/stable/42931193

Vanessa F. (2019). Skilled people or specialists? Knowledge and expertise in copper age vessels from central Italy. McDonald Institute for Archaeological Research, University of Cambridge, Downing Street, CB23EF Cambridge, United Kingdom. Journal of Anthropological Archaeology 55 (2019) 101072.

Retrieved February,2021.

William K. K and Philip K. (2016). The role of pottery production in development: A case study of the Ankole region in Western Uganda. Net Journal of Social Sciences Vol. 4(4), pp. 81-90, Retrieved February, 2021 at http://www.netjournals.org/pdf/NJSS/2016/4/16-023.pdf 